\title{
PSYCHOLOGICAL PRINCIPLES OF STUDENTS-PSYCHOLOGISTS' SUCCESS IN PROFESSIONAL DEVELOPMENT
}

УДК 159.9.075

DOI https://doi.org/10.32843/2663-

5208.2020.13-2.24

\section{Столярчук О.A.}

д.психол.н, доцент,

доцент кафедри психології особистості

та соціальних практик

Київський університет

імені Бориса Грінченка

Сергєєнкова О.П.

д.психол.н., професор,

завідувач кафедри психології

особистості та соціальних практик

Київський університет

імені Бориса Грінченка

Коханова О.П.

к.психол.н.,

доцент кафедри психології особистості

та соціальних практик

Київський університет

імені Бориса Грінченка
У статті проаналізовано результати дослідження парціальних аспектів профресійного самовизначення майбутніх психологів як підгрунтя успішності їхнього фрахового становлення. Актуальність досліджуваної проблеми зумовлена необхідністю оптимізації особистісно-профресійного становлення майбутніх психологів на етапі фрахового навчання. Емпіричне дослідження психологічних засад профресійного становлення майбутніх психологів здійснено з 57 першокурсниками Київського університету імені Бориса Грінченка із використанням методів анкетування, ранжування, середніх значень і якісного аналізу даних. Установлено, що провідними мотивами обрання студентами психологічної просресії є інтерес до цієї науки, визнання престижності профресії психолога, а також настанови близьких. Прагнення допомагати людям займає посередню позицію в рейтингу мотивів профресійного самовизначення. Першокурсники майже не ідентисрікують обрану профресію з покликанням і власними здібностями.

Засріксовано переважання носіїв середнього рівня пропедевтичної професійної самоочінки серед опитаних. Водночас вибірка першокурсників із високою пропедевтичною самооцінкою становить 37\%, що є сприятливим підгрунтям для подальшого фрормування їхньої фахової самооцінки.

Виявлено, що лише 36\% опитаних студентів уважають свої профресійне самовизначення успішним, стільки ж першокурсників позначають його як суперечливе. При цьому ніхто з респондентів не вважає свій вибір помилковим чи нав'язаним іншими людьми. Установлено, що найвагомішими чинниками успішності профресійного становлення майбутніх психологів у їхньому баченні $є$ власна мотивація й зусилля, прагнення до балансу навчальної теорії та практики, компетентність і вимогливість викладачів. Недостатньо актуальними для успішності профресійного становлення респондентів виявлено самоосвіту й саморозвиток, а також зразки роботи психологів.

Ключові слова: профресійне самовизначення, срахове становлення, студент, майбутній психолог, мотивація вибору профресії, пропедевтична професійна самооцінка.
The article analyses the results of the study of partial aspects of professional self-determination of future psychologists as a basis for the success of their professional development. The relevance of the studied problem is due to the necessity of optimizing the personal and professional development of future psychologists at the stage of professional training.

The empirical research of the psychological foundations of the professional development of future psychologists is carried out with 57 first-year students of Borys Grinchenko Kyiv University. Methods of questionnaires, ranking, averages and qualitative data analysis were used. The results of the analysis show that the leading motives for choosing the psychological profession by students is the interest in this science, the recognition of the prestige of the profession of a psychologist alongside attitudes and viewpoints of close people. The desire to help people occupies a middle place in the ranking of professional self-determination's motives. The first-year students almost do not identify the chosen profession with the vocation and their own abilities.

There was the predominance of carriers with an average level of propaedeutic professional self-esteem among the respondents. The sample of first-year students with high propaedeutic self-esteem is $37 \%$. It was identified that only $36 \%$ of the surveyed students consider their professional self-determination to be successful. The same number of first-year students marks it as contradictory. However, none of the respondents suppose their choice to be wrong or imposed by other people.

It was also revealed that the most important factors in the success of professional development of future psychologists in their vision are their own motivation and efforts, striving for a balance of educational theory and practice, competence and demanding teachers.

Self-education and self-development as well as examples of psychologists' work were found to be insufficiently relevant for the successful professional development of the respondents.

Key words: professional self-determination, professional becoming, student, future psychologist, motivation of a professional choose, propaedeutic professional self- appraisal.
Постановка проблеми. Професійне самовизначення особистості розпочинається з вибору майбутнього фаху та формування професійних намірів. Первинним критерієм успішності професійного самовизначення особистості на етапі оптації $€$ усвідомлений вибір професії з урахуванням своїх особливостей і можливостей, вимог фаху й соціально-економічних умов. Загалом фахове самовизначення здійснюється протягом усього професійного життя: особистість постійно рефлексує, переосмислює свої фахові досягнення та перспективи й самореалізується в професії. Первинна актуалізація професійного самовизначення особистості ініціюється такою подією, як закінчення загальноосвітнього навчального закладу. Випускники мають вирішити важливе для майбутнього завдання - обрати професію, збалансувавши власні потреби, нахили й можливості з умовами сучасного ринку праці. Від- 
повідно, в абітурієнтів ЗВО вже сформовано певне підґрунтя для подальшого професійного становлення. Початок фахового навчання випробовує це особистісне підґрунтя, певним чином показуючи сприятливість чи несприятливість його змісту.

Нині в різних сферах діяльності людини та суспільного функціонування зростає актуальність вирішення нагальних психологічних проблем, що зумовлює підвищення вимог до підготовки вітчизняного фахівця-психолога й розширює сфери застосування психологічних знань. Унаслідок реагування на запити суспільства, сучасна система психологічної освіти пропонує майбутнім абітурієнтам різні спеціалізації в межах професії.

Фахове навчання має сприяти ефективному становленню майбутнього психолога через набуття компетентності, формування професійно важливих якостей, розкриття його творчого потенціалу, визначення свого місця в професії. За таких умов викладачам важливо орієнтуватися в змісті професійного самовизначення майбутніх психологів задля побудови успішної взаємодії з ними в межах освітнього процесу.

Аналіз останніх досліджень і публікацій. Проблема структурно-функціональних проявів професійного самовизначення потрапляла у фокус вивчення багатьох вітчизняних науковців. Так, питання мотивації професійноговиборумайбутнімипсихологамизачіпали Ж.П. Вірна, І.М. Галян, О.І. Галян, В.А. Семиченко, Л.І. Подшивайлова, Н.В. Чепелєва та ін. Дослідники О.І. Галян, І.М. Галян, аналізуючи особливості формування мотиваційно-ціннісного компонента в професійному самовизначенні особистості, виокремили такі особистісні детермінанти професійного вибору майбутніх психологів:

- комплекс мотивів професійного вибору (професійна мотивація психологів, чинники привабливості професії тощо);

- професійно-ціннісні орієнтації;

- особистісні конструкти;

- особистісні настанови;

- уявлення про «ншого» як цінність у практиці надання психологічної допомоги [2, c. 128].

Цілком погоджуючись із вищевикладеною тезою, уважаємо доречним виявлення психологічних засад професійного становлення майбутніх психологів задля оптимізації цього процесу.

Постановка завдання. Метою статті євикладтааналіз результатів дослідженняпарціальних аспектів професійного самовизначення майбутніх психологів як підґрунтя успішності їхнього фахового становлення. Емпіричне дослідження психологічних засад професійного становлення майбутніх психологів здійс- нено зі студентами першого курсу освітніх програм «Психологія бізнесу та управління», «Консультаційна психологія», «Практична психологія» Київського університету імені Бориса Грінченка. Вибірка становила 57 осіб віком від 17 до 19 років. У процесі дослідження використано методи анкетування, ранжування, середніх значень і якісного аналізу даних.

Виклад основного матеріалу дослідження. Ключовим чинником професійного самовизначення юнацтва є мотивація вибору професії. На підставі опитування першокурсників установлено, що провідним мотивом обрання ними психологічної професії постав інтерес до цієї науки. На другій позиції рейтингу знаходиться визнання престижності професії психолога, а третє місце посів мотив настанов близьких (таблиця 1). Отже, складається картина домінування дещо другорядних стосовно змісту професійної діяльності психолога мотивів вибору цього фаху опитаними першокурсниками. На четвертому місці опинився традиційний мотив - прагнення вирішити власні психологічні проблеми. Попри численну критику науковцями значущості цього мотиву, ми вбачаємо в ньому актуальний профіцитарний зміст. Потреба вирішити власні психологічні потреби свідчить про рефлексивні вміння, потенціал особистісного розвитку та готовність його реалізовувати.

На п'ятій і шостій рейтингових позиціях фігурують мотиви, які відображають підприємницькі схильності опитаних, що $€$ абсолютно природним, зважаючи на початок дорослого життя й урізноманітнення їхніх потреб. Альтруїстичний мотив допомагати людям перегукується з інтересом до роботи з ними, і ця синергія посилює дієвість обох мотивів. Прагматична орієнтація на отримання диплома про вищу освіту наявна, але не має провідного значення. Цікаво, що мотив покликання теж майже ігнорується досліджуваними. Припускаємо, що це свідчить про низьку семантичну обізнаність щодо самого поняття першокурсниками, а також недостатнє усвідомлення змісту власного покликання на старті професійного становлення. Підтвердженням цього припущення може стати й остання позиція рейтингу мотивів, оскільки досліджувані майже не ідентифікують обрану професію з власними здібностями. Загалом рейтинг мотивів вибору професії психолога, відтворений першокурсниками, має досить еклектичний характер, оскільки провідні мотиви поєднують інтелектуальні, соціальні та комунікативні вектори змісту, внутрішне й зовнішне походження мотивації. Водночас пріоритет інтересу до психології стає сприятливим полігоном для подальшого формування професійної компетентності студентів. 
Результати дослідження перегукуються в цьому контексті з даними латвійських психологів, які встановили, що найважливішими мотивуючими факторами для вивчення психології у вибірці студентів першого курсу віком від 8 до 43 років академічної та професійної програми психології $€$ інтерес до психології й бажання допомогти людям у вирішенні особистісних проблем [5].

Також про домінування внутрішньої мотивації професійного вибору свідчать емпіричні дані австралійських учених. Їхні дослідження вказують на спричиненість вибору психологічної професії студентами обох статей поєднанням внутрішніх і зовнішніх мотиваторів, включаючи навчання в цікавій галузі, потреби підвищення знань і розуміння поведінки людини, прагнення до особистісного зростання й розвитку, бажання допомагати іншим, розширення варіантів кар'єри та її побудова саме в психології [3].

Посилення внутрішньої мотивації відбувається під час опанування особистістю психологічного фаху в межах другої вищої освіти, як установлено вітчизняним науковцем О.І. Галяном. Він зазначає, що в майбутніх психологів, які здобувають другу вищу освіту за спеціальністю «Практична психологія», домінуючими $€$ внутрішні мотиви, у яких відображено як прагнення до самореалізації, так і налаштованість на психологічну допомогу іншим при високому почутті відповідальності за результати свої діяльності [1, с. 198].

Професійне навчання $є$ сензитивним для формування професійної самооцінки студентів, яка $€$ важливим складником Я-концепції майбутнього фахівця. Платформою для формування фахової самооцінки студента може стати його пропедевтична професійна самооцінка, що активізується в процесі вибору старшокласником майбутнього фаху. Результати дослідження вказують на розповсюдженість носіївсередньогорівняпропедевтичноїпрофесійної оцінки серед опитаних (45\%). Більше ніж третина респондентів оцінили свої можливості стати кваліфікованим психологом як високі.

Натомість 7\% першокурсників позначили рівень власної пропедевтичної професійної оцінки як низький, а 11\% першокурсників зізналися, що взагалі не оцінювали свій потенціал із позиції перспектив успішності здобуття психологічного фаху (рис. 1). Загалом досить високий відсоток носіїв високої пропедевтичної професійної самооцінки на тлі незначної кількості студентів з низькою та невизначеною самооцінкою створює сприятливе підґрунтя для подальшого формування їхньої професійної самооцінки.

Початок професійного навчання уможливив первинну рефлексію успішності вибору професії студентами. За даними дослідження, трохи більше ніж третина (36\%) опитаних уважає своє професійне самовизначення успішним, стільки ж студентів позначили його суперечливим (рис. 2). Майже два десятки респондентів визнають неостаточним свій теперішній вибір професії, оскільки обрали позначення відстроченого фахового самовизначення.

Десята частина першокурсників узагалі ще не визначилася з майбутньою професією. Проте жоден із опитаних студентів не підтвердив, що привласнив у виборі професії думку інших, позаяк відсутній вибір нав'язаного типу фахового самовизначення. Також ніхто з респондентів не вважає свій вибір помилковим. Відповідно, попри невеликий відсоток виборів студентами успішного типу професійного самовизначення, складається картина досить обережного й критичного його аналізу опитаними. Результати цього аналізу, очевидно, будуть переглядатися майбутніми психологами впродовж подальшого фахового навчання.

Інший вектор рефлексії студентів охоплював питання детермінації успішності їхнього професійного становлення на етапі фахового навчання. Власна мотивація й зусилля як домінуючий чинник успішності професійного становлення майбутніх психологів у їхньому

Рейтинг мотивів вибору професії психолога серед першокурсників

Таблиця 1

\begin{tabular}{|l|c|c|}
\hline \multicolumn{1}{|c|}{ Мотив } & Рейтингова позиція & Середня кількість балів \\
\hline Бажання вдосконалити знання з психології & 1 & 8,2 \\
\hline Престижність обраної професії & 2 & 7,7 \\
\hline Настанови близьких & 3 & 7,6 \\
\hline Потреба вирішити власні психологічні проблеми & 4 & 7,5 \\
\hline Перспективи побудови успішної кар'єри & 5 & 7,4 \\
\hline Прагнення мати гарний заробіток & 6 & 7,3 \\
\hline Бажання допомагати людям & 7 & 7,2 \\
\hline Інтерес до роботи з людьми & 8 & 6,4 \\
\hline Прагнення мати диплом про вищу освіту & 9 & 5,8 \\
\hline Покликання & 10 & 5,5 \\
\hline Відповідність обраної професії здібностям & 11 & 3,2 \\
\hline
\end{tabular}


баченні свідчить про становлення їхньої суб'єктної позиції (таблиця 2). Також виправдано значущим для професіоналізації постає прагнення першокурсників до балансу навчальної теорії та практики. Третє місце рейтингу поділили між собою два зовнішні чинники компетентність і вимогливість викладачів, а також сприятливий мікроклімат в академічній групі. Значущість стосунків 3 одногрупниками є зрозумілою з позиції розгортання адаптаційних процесів у першокурсників, що підтверджується й вагомістю для них доброзичливого ставлення викладачів як наступного чинника в рейтингу. Потреба збалансованості для опитаних їхнього внутрішнього особистісного стану та зовнішніх умов навчання відображена на шостій рейтинговій позиції.

Другорядними чинниками успішності професійного становлення респондентів виявлено самоосвіту й саморозвиток, а також зразки роботи психологів. Менше за все першокурсники пов'язують успішність власної професіоналізації з можливостями поєднувати навчання й роботу та налагодженим особистим життям. Отже, правильна позиція першокурсників щодо першочергової значущості власної мотивації та зусиль супроводжується недооцінкою ролі самоосвіти й саморозвитку. Безперечно, дається взнаки обмеженість досвіду професійного становлення, зумовлена його початком щодо опитаних студентів першого курсу.
Вид самооцінки (\% носіїв)

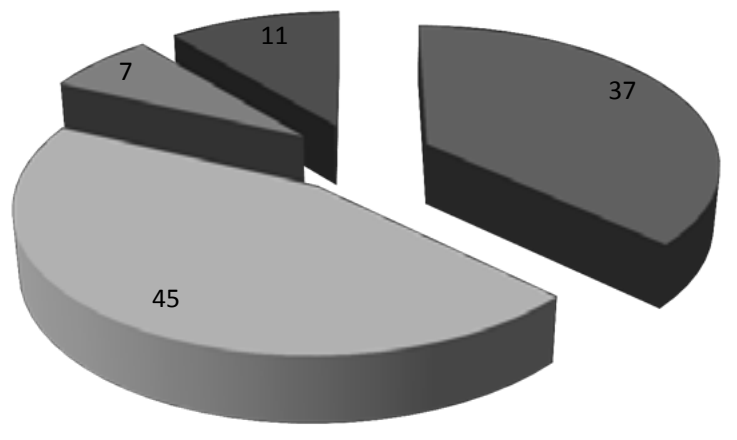

- Висока

$\square$ Середня

- Низька

- Невизначена

Рис. 1. Розподіл студентів за рівнем пропедевтичної професійної самооцінки

Тип самовизначення (\% носіїв)

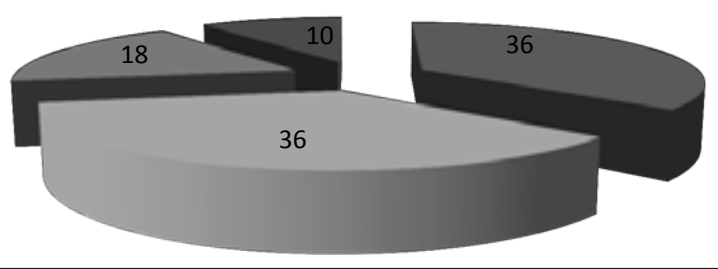

- Успішний

Суперечливий

- Відстрочений

- Невизначений

\section{Рис. 2. Позначення студентами типу власного професійного самовизначення}

Важливо взяти до уваги результати напрацювання інших дослідників щодо предиктів задоволеності студентів освітніми програмами здобуття психологічного фаху. Канадські вчені, які вивчали цю проблему зі 237 випускниками бакалаврської програми з психології, визначали чинники задоволення студентів цією програмою. Хоча психологія - одна з найпопулярніших спеціальностей для студентів у Північній Америці, але рівень задо-

Чинники успішності професійного становлення майбутніх психологів

\begin{tabular}{|l|c|c|}
\hline \multicolumn{1}{|c|}{ Чинник } & Рейтингова позиція & Середня кількість балів \\
\hline Власна мотивація й зусилля & 1 & 9,2 \\
\hline Баланс навчальної теорії та практики & 2 & 8,8 \\
\hline Компетентність і вимогливість викладачів & 3 & 8,5 \\
\hline Сприятливий мікроклімат в академічній групі & 3 & 8,5 \\
\hline Доброзичливе ставлення викладачів & 4 & 8,4 \\
\hline Власна психологічна рівновага & 5 & 8,2 \\
\hline Прийнятні матеріально-побутові умови навчання & 5 & 8,2 \\
\hline Системні самоосвіта й саморозвиток & 6 & 8,1 \\
\hline Зразки роботи професіоналів & 7 & 7,8 \\
\hline Можливості поєднувати навчання й роботу & 8 & 7,7 \\
\hline Налагоджене особисте життя & 9 & 7,2 \\
\hline
\end{tabular}


воленості випускників освітньою програмою $€$ різним. Трирічний аналіз показав, що ключовими прогнозами ступеня задоволеності студентів освітньою програмою є якість викладання на лекціях, рівень навчальних викликів і можливості для дослідницького досвіду. Додатковий аналіз засвідчив, що студенти, які потребували подальшого наукового дослідження та планували захист дисертації, повідомили про значно більшу задоволеність, ніж студенти звичайних спеціальностей [4]. Ці результати підтверджують доречність реалізації навчання, базованого на дослідженнях, із майбутніми психологами як полігону для втілення їхніх індивідуальних освітніх запитів і посилення внутрішньої мотивації їхнього особистісно-професійного становлення

Висновки 3 проведеного дослідження. Отже, у процесі вивчення парціальних аспектів професійного самовизначення майбутніх психологів установлено, що домінуючими мотивами обрання ними професії $€$ інтерес до психології, визнання престижності фаху, а також настанови близьких. Прагнення допомагати людям займає посередню позицію в рейтингу мотивів професійного самовизначення. Першокурсники майже не ідентифікують обрану професію з покликанням і власними здібностями.

Зафіксовано переважання носіїв середнього рівня пропедевтичної професійної самооцінки серед опитаних. Виявлено, що лише 36\% опитаних студентів уважають своє професійне самовизначення успішним, стільки першокурсників позначають його як суперечливе. При цьому ніхто з респондентів не вважає свій вибір помилковим чи нав'язаним іншими людьми.

Установлено, що найвагомішими чинниками успішності професійного становлення майбутніх психологів у їхньому баченні $€$ власна мотивація й зусилля, прагнення до балансу навчальної теорії та практики, компетентність і вимогливість викладачів. Недостатньо актуальними для успішності професійного становлення респондентів виявлено самоосвіту й саморозвиток, а також зразки роботи психологів. Ці неоднозначні, а іноді й суперечливі показники парціальних аспектів професійного самовизначення майбутніх психологів указують на доречність здійснення психологічного супроводу їхнього фахового становлення.

Перспективи подальших досліджень убачаємо в установленні зв'язків між детермінантами професійного вибору та мотивацією фахового навчання.

\section{ЛIТЕРАТУРА:}

1. Галян О.І. Мотиваційний аспект професійного вибору майбутніх психологів (на прикладі студентів центру перепідготовки). Науковий вісник Львівського державного університету внутрішніх справ. Серія «Психологічна». 2013. Вип. 2. С. 194-202.

2. Галян О.І., Галян І.М. Мотиваційно-ціннісний компонент професійного вибору майбутніх психологів на етапі оптації. Науковий вісник Львівського державного університету внутрішніх справ. Серія «Психологічна». 2012. Вип. 1. С. 122-131.

3. Apat D., Christophers L., Van der Kooji C., Lowndes T., McCagh H., Omaquasha D. \& Wyatt A. Why students choose to study psychology and their level of satisfaction with the course. URL: http://www.murdoch.edu.au/School-of-Psychology-andExercise-Science/Research/Psychology-Research/ Why-students-choose-to-study-psychology/.

4. Sears C.R., Boyce M.A., Boon S.D., Goghari V.M., Irwin K. and Boyes M. Predictors of student satisfaction in a large psychology undergraduate program. Canadian Psychology. 2016. № 58 (2). P. 148-160.

5. Upmane A., Gaitniece-Putāne A., Šmitina A. Psychology Students Personality Traits and Motivation to Choose Studies. Society. Integration. Education. Proceedings of the International Scientific Conference. Volume I. May 27th-28th, 2016. P. 540-552. 